\title{
The Protection of Illegal Immigrants under Indonesian National Law and International Law
}

\author{
Anis Widyawati ${ }^{1 \mathrm{a}}$, Ridwan Arifin ${ }^{1 \mathrm{~b}}$ \\ ${ }^{1}$ Faculty of Law, University Negeri Semarang, Indonesia \\ anis@mail.unnes.ac.id, ${ }^{b}$ ridwan.arifin@mail.unnes.ac.id
}

\begin{abstract}
War around the world affected in many human aspects, not only in economic, education and social, but also to law and justice, as well as human rights protection. Immigrant in the global context was protected by International Convention under International Law Regime. The immigrant should put at the same place as human commonly, but in many cases there are some violations of human rights to immigrants. Protection of illegal immigrants should provide by State as a basic human rights fulfillment. The protection related to a wide range of protection including health, education, social, and cultural rights. This paper would examine how illegal immigrants protected by Indonesian national law and international law. Authors will compare some cases concerning to illegal immigrants in Indonesia.
\end{abstract}

\section{Keywords-Illegal Immigrant, Protection, Indonesian Law, International Law}

\section{INTRODUCTION}

Indonesia has long faced problems with foreign asylum seekers and refugees. Being among the recipient countries of asylum seekers and refugees in large numbers such as Malaysia, Thailand and Australia, Indonesia is continually affected by mixed population movements. After the decline in numbers in the late $1990 \mathrm{~s}$, the number of asylum seekers coming to Indonesia increased again in 2000, 2001 and 2002. Although the number of arrivals later declined again in 2003-2008, the arrival trend again increased in 2009 with 3,230 people request protection through the United Nations High Commissioner for Refugees (UNHCR). Currently the majority of asylum seekers come from Afghanistan, Myanmar and Somalia. Data on the arrival of asylum seekers who registered at UNHCR year after year: 385 in 2008; 3,230 in 2009; 3,905 in 2010 and 4,052 in 2011, 7,223 in 2012, and 8,332 in 2013.

The phenomenon of migration is not new. For centuries, humans have traveled to find a better life in another place. In the last few decades, the process of globalization has increased factors that encourage immigrants to seek their fortune abroad. On January 12, 2009 Indonesia ratified the UN Convention Against Organized Transnational Crimes in 2000 (which was then called the Palermo Convention in 2000) through Law Number 5 of 2009, and in the same year precisely on March 16, Indonesia also ratified the Protocol Against the Smuggling of Migrants Through Land, Sea and Air in 2004 (hereinafter referred to as the 2004 Migrant Smuggling Protocol) through Law Number 15 of 2009.

Indonesia as a country in the world also has strong potential for transnational crime. Transnational crime is not only driven by factors of free trade that are wide open or weak law enforcement in Indonesia. But it is also supported by the geographical area of Indonesia itself. Indonesia whose form is archipelago, [1] geographically has many entrances: airports, ports, land and water boundaries. In addition, Indonesia, which also has a very long coastline, and is an area that is located in a cross-border position of world trade traffic, is also a major factor that causes it to have strong potential for transnational crime.[2]

In Indonesia itself, this happens on average every year up to 2011 more than 10,000 illegal immigrants both make Indonesia a destination and as a transit. This smuggling is intended to supply the international sex trade market and laborers. The smuggling is carried out through organized international crime networks both through intermediate and direct state channels. The significant increase in the activity of organized crime groups in the occurrence of migrant' smuggling, can endanger countries and the lives and safety of migrants themselves. Therefore, the international community agreed to regulate additional protocols on migrant smuggling.[2]

The practice of people smuggling has increased in the past few decades and at present, significant reports of the number of illegal immigration continue to increase in various countries. Smuggling can generally occur with the consent of people or groups who want to be smuggled, and the most common reason for them is the opportunity to get a job or improve economic status, the hope of getting a better life for themselves or family.[2] People smuggling and illegal immigrants is a criminal act that hooks each other up. Such activities can occur if one of them can be realized, in the sense that illegal immigrants will succeed with the conspiracy of smuggling agents, and people smugglers result in an increasing number of illegal immigrants.[3] Illegal immigrants who later in many references are referred to as illegal immigrants, always referring to the Migrant Smuggling Protocol in 2004, states that illegal immigrants are immigrants who enter illegally or cross national boundaries by not complying with the requirements required to enter lawfully into in a country. What is meant by not complying with the requirements 
required to enter is the entry of immigrants into a particular country without completing travel documents or using official travel documents but using a false identity.[4]

Meanwhile, Indonesia is always positioned as a "transit" country for illegal immigrants to the destination country, one of which is Australia. But the definition of transit country seems to have to be revisited, considering that many of them later made Indonesia a "final" country. In 2013 the tendency for illegal immigrants to enter Indonesia to rise by $12 \%$, which if Indonesia (as a sovereign country) does not have an effective formula for the problem of illegal immigrants in the country it is undeniable that in the coming year Indonesia will be flooded with illegal immigrants, which will have an impact on economy, security and employment opportunities of the Indonesian population.[5]

\section{RESEARCH METHOD}

This paper analyzes various cases relating to legal protection for illegal immigrants both in national legislation in Indonesia and international regulations. The analysis used in this paper compares the results of previous research related to illegal immigrants. This paper analyzes some laws and regulations, such as Law No. 6 of 2011 concerning Immigration, following Government Regulation Number 31 of 2013 concerning Implementing Regulations of Law No.6 of 2011 concerning Immigration, Law Number 12 of 2006 concerning Citizenship, Law Number 5 of 2009 concerning United Ratification The Nations Convention Against Transnational Organized Crime, Law No. 14 of 2009 concerning the Ratification of the Protocol to Prevent, Suppress and Punish Trafficking in Persons, Especially Women and Children, Supplementing the United Nations Convention Against Transnational Organized Crime, Law No.15 of 2009 on Ratification of the Protocol Against The Smuggling of Migrants by Land, Sea and Air, Supplementing the United Nations Convention Against Transnational Organized Crime. United Nations Convention Against Transnational Organized Crime; Protocol Against The Smuggling of Migrants by Land, Sea and Air, Supplementing United Nations Convention Against Transnational Organized Crime Year 2000; and Protocol to Prevent, Suppress and Punish Trafficking in Persons, Especially Women and Children, Supplementing United Nations Convention Against Transnational Organized Crime Year 2003.

\section{RESULT AND DISCUSSION}

\section{A. Illegal Immigrants under Indonesian National Law and International Law}

The legal framework at the international level, the Convention on Refugees in 1951 and the Protocol on Refugees in 1967, provides several regulatory provisions regarding the basic definition of refugees, along with terms including refugees and those excluded from so-called refugees, as well as refugee status. Regulate the legal status of refugees in asylum countries, their rights and obligations, including the right to be protected from forced repatriation, or returned to areas where their lives or freedoms are threatened. It also regulates state obligations, including cooperating with UNHCR in carrying out its functions and facilitating its duties to oversee the implementation of the 1951 Refugee Convention. Jamin Ginting explained that related to the authorities, not only the national government strives forward to overcome those illegal practices, but also the international communities consider it is necessary to have the international legal instruments which strictly prohibit and penalize those crimes.[6]

Therefore, within the legal framework of illegal immigrants some of the conventions that govern are the United Nations Convention on Organized Crime / Palermo Convention of 2000 (United Nations Convention Against Transnational Organized Crime); Protocol Against The Smuggling of Migrants by Land, Sea and Air, Supplementing the United Nations Convention Against Transnational Organized Crime Year 2000; and Protocol to Prevent, Suppress and Punish Trafficking in Persons, Especially Women and Children, Supplementing the United Nations Convention Against Transnational Organized Crime Year 2003.

National law or referred to as the positive law of a country is a collection of written legal principles and rules that are currently in force and binding in general or specifically and are enforced by or through the government or the courts in the state.[7] In Indonesia, the national legal framework governing illegal immigrants is spread in several laws and regulations, namely Law No.6 of 2011 concerning Immigration, following the Regulations Government Number 31 of 2013 concerning Implementing Regulations of Law No.6 of 2011 concerning Immigration, Law Number 12 of 2006 concerning Citizenship, Law Number 5 of 2009 concerning Ratification of the United Nations Convention Against Transnational Organized Crime, Act No. 14 of the Year 2009 on the Ratification of the Protocol to Prevent, Suppress and Communicable Trafficking in Persons, Especially Women and Children, Supplementing the United Nations Convention Against Transnational Organized Crime, Law 15 of 2009 concerning the Ratification of the Smuggling of Migrants Protocol by Land, Sea and Air, Supplementing the United Nations Convention Against Transnational Organized Crime.

The United Nations Convention Against Transnational Organized Crime and its two additional protocols are forms of international treaties that bind countries that sign them, giving rise to rights and obligations for these countries. However, an international agreement does not directly bind the countries that sign it. According to the Mauna Boer, the attachment to international agreements depends on the provisions of the national law of each country.[8]

So far, the handling of illegal immigrants in Indonesia is carried out using the Immigration Act, Law Number 6 of 2011 which has adopted the principles set out in the United Nations Convention Against Transnational Organized Crime and its two additional protocols. Through immigration laws, the state has the right to regulate the presence of foreigners in the territory of the Republic of 
Indonesia. Indonesia as a sovereign country has the right to be able to regulate the existence of illegal immigrants, both those who come with documents and those who are undocumented. However, in the implementation of this Law, it is deemed not yet able to effectively regulate the existence of illegal immigrants in Indonesia. The use of the word illegal immigrants shows that asylum seekers and refugees are still considered part of immigrants in general, not in another category, namely refugees. Indonesian immigration refusal to qualify asylum seekers and refugees in a special category not as illegal immigrants on the grounds that Indonesia has not ratified the 1951. refugee convention.[9]

Law Number 6 of 2011 provides a definition of people smuggling in Article 1 Number 32, namely: People smuggling is an act that aims to make a profit, either directly or indirectly, for yourself or for others who bring a person or group of people, either organized or unorganized, or instruct others to bring someone or group of people, both organized and unorganized, who do not have the legal right to enter Indonesian territory or exit the territory of Indonesia and / or enter the territory of another country where the person does not have the right to enter the area legally, either by using legal documents or fake documents, or without using a Travel Document, whether through immigration inspection or not.[10]

The provisions in the form of criminal sanctions are only aimed at immigrant smugglers, in Article 120 of Law No. 6 of 2011 concerning Immigration, namely: Anyone who commits an act that aims to seek profit, either directly or indirectly, for themselves or for another person who carries a person or group of people, either organized or unorganized, or orders others to bring a person or group of people, both organized and unorganized, who do not have the legal right to enter Indonesian territory or leave the territory of Indonesia and / or enter the territory of another country that the person does not have the right to enter the area legally, either by using legal documents or fake documents, or without using a Travel Document, whether through immigration checks or not, convicted of Human Smuggling with imprisonment of at least 5 (five) years and a maximum of 15 (fifteen) years and a fine of at least Rp.500,000,000.00 (five hundred million rupiah and a maximum of Rp.1,500,000,000.00 (one billion five hundred million rupiah).[10]

\section{B. Protection of Illegal Immigrants in Indonesia}

In several laws and regulations the Indonesian Government recognizes the right of every person to seek asylum in other countries, as in the 1945 Constitution of the Republic of Indonesia. "Every person has the right to be free from torture or treatment that undermines human dignity and is entitled to political asylum from other countries",[11] in the MPR Decree "Everyone has the right to seek asylum to obtain political protection from other countries",[12] in Law No. 39 of 1999, "Everyone has the right to seek asylum to obtain political protection from other countries",[13] as well as in Law Number 37 of the Year 1999 concerning Foreign Relations[14] mandates implementing regulations on handling foreigners asylum seekers and refugees. However, the draft implementing regulation in the form of the presidential regulation is still in the process of discussion. In Article 25 the authority to grant asylum to foreigners is in the hands of the President, taking into account the minister's consideration. The implementation of this authority is mandated by a Presidential Decree. In Article 27 the President also stipulates a policy on the problem of refugees from abroad as well as taking into account the minister's consideration. The policy principles are also mandated by the Presidential Decree. The purpose of Article 25 and Article 27 of Law Number 37 of 1999 which mandates the policy rules for handling asylum seekers and refugees is regulated by a Presidential Decree, because at that time the Presidential Decree was still included in the type and hierarchy of laws and regulations. After the enactment of Law Number 12 of 2011 concerning the Establishment of Laws and Regulations[15], it is determined that the Presidential Decree is no longer included in the type and hierarchy of laws and regulations.

Law No. 6 of 2011 concerning Immigration does not recognize the terms of asylum seekers or refugees, and in regulated norms, Indonesia is not burdened with any obligation (legal, social and political) in dealing with asylum seekers and refugees. Indonesia is one of the favorite places for asylum seekers or international refugees as a place to stop. The problem arises when the government is not responsive in handling the asylum seekers and refugees. Because Indonesia has not ratified the 1951 International Convention and the 1967 Protocol, the government cannot immediately determine the status of asylum seekers or refugees. Status determination is carried out by UNHCR which takes a long time. This condition is worsened by the absence of implementing regulations that regulate similar matters.

Indonesia does have foreign relations which mandates refugees and asylum seekers. This provision should have been followed up, but for the past fifteen years the implementing regulations have never been passed and are still being discussed. As a result, when there was a group of foreigners who entered Indonesian territory, they were categorized as illegal immigrants who committed immigration administration violations as the Immigration Act. So that the group of foreigners is grouped into one and placed in the Immigration Detention Center (Rumah Detensi Imigrasi, Rudenim).

On the other hands, the Indonesian government is not a country that ratified the 1951 Convention and the 1967 Protocol. Therefore, determining the status of refugees or asylum seekers against immigrants is carried out by UNHCR. This determination is important to prevent pillion people who have different motives. The pillion is usually associated with criminal activities such as human trafficking, war crimes and so on. On the other hand, the long waiting period for refugees and asylum seekers for the clarity of their status has the potential to cause human rights violations. Because the length of the process of clarity of status can cause psychological distress for refugees and asylum seekers. 
Asylum seekers and refugees are an international problem but because Indonesia is a haven, the problem is a domestic problem. To overcome this it is necessary for the government to ratify the 1951 Convention and the 1967 Protocol. There are two benefits that Indonesia can obtain if it ratifies. First, the government can determine the status of refugees and asylum seekers themselves so that the government can be directly involved and contribute to the handling of this problem in accordance with national interests. It can also be ascertained that the search for asylum is not used as a tool for the escape of people involved in criminal acts and crimes under international law. Second, the government can receive international assistance and cooperation related to strengthening national capacity in handling asylum seekers and refugees. So that the solution can be done comprehensively. Besides that, the burden of handling asylum seekers and refugees is not borne entirely by the government but also supported by solidarity and cooperation with the international community.

Some of the factors that caused Indonesia to be chosen as a transit country include the first, Indonesia has a vast sea area and a long coastline, however, it is not supported by strict legal rules. So that it is easily utilized by refugees and asylum seekers to enter Indonesian territory. Second, Indonesia's position is very weak in overcoming the problem of asylum seekers and refugees from other countries because they do not have national regulations that specifically address the issue. Third, the lack of facilities and infrastructure in handling refugees and asylum seekers to monitor Indonesian waters intensively. Fourth, the existence of UNHCR in Jakarta is also an attraction for refugees. Fifth, the culture or culture of the Indonesian people, which is known for its hospitality, creates the impression that Indonesian people can easily accept the arrival and presence of refugees. And sixth, Indonesia has lived harmoniously with various ethnic groups, religions and cultures.

\section{CONCLUSION}

The problem of illegal immigrants is not only a matter of state sovereignty but also a matter of protecting basic human rights. The absence of adequate legal instruments could be the cause of human rights violations especially for illegal immigrants. Protection of illegal immigrants, although regulated nationally and internationally, but has not specifically provided adequate protection. Both international and national legal instruments, both still have weaknesses in presenting protection for illegal immigrants.

\section{REFERENCES}

[1] T. May Rudy, Hukum Internasional, (Bandung: PT. Refika Aditama, 2009.

[2] Sam Fernando, "Politik Hukum Pemerintah (Direktorat Jenderal Imigrasi) Dalam Menanggulangi Masalah Penyelundupan Manusia”, .Jurnal Pascasarjana Universitas Brawijaya, Volume 8 No. 2, 2013.

[3] Kadarudin, "People Smugling dalam Perspektif Hukum Internasional dan Penegakan Hukumnya Di Indonesia", Jurnal Perpustakaan, Informasi dan Komputer “Jupiter" Volume XII No.2 June, 2013.

[4] Article 3 points b and c of the Protocol Against Smuggling of Migrants Through Land, Sea and Air.

[5] Bambang, Deputy V / Bidkoor Kamnas Kemenko Polhukam 'Indonesian Policy on Illegal Immigrants Regarding Sovereignty and State Responsibility' 2013 (Djokosoetono Research Center UI Seminar)

[6] Jamin Ginting, "Roles of the Mutual Legal Assistance and Extradition Agreements in The Assets Recovery in Indonesia", IJIL UI, Vol. 9 No. 2, 2012.

[7] Bagir Manan, Hukum Positif Indonesia: Suatu Kajian Teoritik, FH UII Press, 2010.

[8] Eva Johan," Tindak Pidana Trafficking Anak menurut Hukum Pidana Internasional dan Implikasi dari Lahirnya Undnag-Undang Nomor 14 Tahun 2009", Litigasi FH UNPAS, Vol. 13 No. 1, 2012.

[9] Fitria, "Penanganan pencari suaka dan pengungsi di indonesia:dilema peraturan setengah hati", on Heru Susetyo, Heri Aryanto, Ryan Muthiara Wasti(ed), Rohingya Suara Etnis Yang Tidak Boleh Bersuara, PIARA PAHAM Indonesia, 2013.

[10] Law No. 6 of 2011 concerning to Immigration (Indonesia Immigration Law)

[11] The Constitution of Republic Indonesia 1945

[12] MPR Decree, Tap MPR

[13] Law No. 39 of 1999 concerning to Human Rights (Indonesia Human Rights Law

[14] Law No. 37 of 1999 concerning Foreign Relations

[15] Law No. 12 of 2011 concerning the Establishment of Laws and Regulations 